\title{
Iconoclasistas: ações cartográficas no Antropoceno
}

\author{
Iconoclasistas: Cartographic Actions \\ in the Anthropocene
}

\section{Iconoclasistas: acciones cartográficas en el Antropoceno}

Hernán Lopez Piñeyro*

http://dx.doi.org/10.22409/poiesis. 1932.87-106

\begin{abstract}
RESUMO: Este artigo analisa quatro cartografias realizadas em oficinas de mapeamento coletivo propostas pelo Iconoclasistas, um grupo de artistas argentinos cujas práticas podem ser entendidas como arte ativista. Esses mapas abordam questões relacionadas ao Antropoceno, tais como o neoextrativismo, o consumo, o lixo e os movimentos sociais. Partindo de algumas ideias de Rancière, afirma-se que essas imagens constituem sistemas de evidências sensíveis que mostram a existência de um comum e as divisões que os atravessam. O mapeamento, como prática crítica, acompanha, divulga as lutas, tece laços e cria formas alternativas de sociabilidade.

PALAVRAS-CHAVE: cartografias; arte ativista; Antropoceno; movimentos ambientais
\end{abstract}

\footnotetext{
*Hernán Lopez Piñeyro é doutorando em Filosofia na Facultad de Filosofía y Letras da Universidad de Buenos Aires. E-mail: hernanlopezpineyro@gmail.com
} 
ABSTRACT: This paper analyzes four cartographies carried out in collective mapping workshops proposed by Iconoclasistas, a group of Argentine artists whose practices can be understood as activist art. These maps address issues related to the Anthropocene, such as neoextractivism, consumption, waste and social movements. Starting from some ideas of Rancière, it is affirmed that these images constitute systems of sensible evidences that show the existence of a common and the divisions that cross them. Mapping, as a critical practice, accompanies, spreads struggles, builds links and creates alternative forms of sociability.

KEYWORDS: cartographies; activist art; Anthropocene; environmental movements

RESUMEN: En este artículo se analizan cuatro cartografías realizadas en talleres colectivos de mapeo propuestos por Iconoclasistas, un grupo de artistas argentino cuyas prácticas pueden ser entendidas como arte activista. Dichos mapas abordan cuestiones relativas al Antropoceno, tales como el neoextractivismo, el consumo, los residuos y los movimientos sociales. Partiendo de algunas ideas de Rancière, se afirma que estas imágenes constituyen sistemas de evidencias sensibles que muestran la existencia de un común y las divisiones que los atraviesan. El mapeo, en tanto que práctica crítica, acompaña, difunde las luchas, teje lazos y crea formas de sociabilidad alternativas.

PALABRAS CLAVE: cartografía; arte activista; Antropoceno; movimientos ambientalistas

Recebido: 01/11/2018; Aprovado: 12/12/2018

Como citar: PIÑEYRO, Hernán Lopez. Iconoclasistas: ações cartográficas no Antropoceno. Poiésis, Niterói, v. 19, n. 32, p. 87-106, jul./dez. 2018. doi: http://dx.doi.org/10.22409/poiesis.1932.87-106

Poiésis, Niterói, v. 19, n. 32, jul./dez. 2018. 


\section{Iconoclasistas: ações cartográficas no Antropoceno}

\section{Arte activista y el proceso de ambientalización de las luchas}

Iconoclasistas, integrado por Julia Risler y Pablo Ares y surgido en el año 2006, transita los caminos del arte, el diseño y la investigación en ciencias sociales. En sus acciones, mayormente cartográficas, el grupo profana el lenguaje del mundo publicitario y del diseño gráfico para, según sus palabras, "producir recursos de libre circulación, apropiación y uso, para potenciar la comunicación, tejer redes de solidaridad y afinidad e impulsar prácticas colaborativas de resistencia y transformación". (ICONOCLASISTAS, 2013, p. 78) El dúo organiza también talleres creativos e investigaciones colectivas, que se iniciaron en el año 2008 y que se replican también de manera independiente del propio grupo.

Iconoclasistas, según entiendo, forma parte de una segunda generación de lo que suele denominarse arte activista desarrollado en la posdictadura argentina. ${ }^{1}$ Al decir de Ana Longoni, los colectivos de arte activista "abrevan en recursos artísticos con la voluntad de tomar posición e incidir de alguna forma en el territorio de lo político". (LONGONI, 2009, p. 18) Para ello ponen en práctica nuevos modos de activismo social y cultural utilizando lenguajes, a veces renovados y a veces no tanto, a veces más "puros" y a veces más 
"contaminados", de las artes visuales, las artes audiovisuales, la poesía, el periodismo alternativo y las humanidades. Es decir, estos grupos no se caracterizaron por utilizar un mismo tipo de formato, pues en sus prácticas pueden encontrarse desde cuadros de caballete hasta propuestas más experimentales como intervenciones urbanas o performances.

A su vez, muchos de estos artistas forman parte, en algunos casos, y dialogan, en otros, con organizaciones territoriales y de derechos humanos que surgieron o tomaron una nueva fuerza en el cambio de siglo. Pues, todos ellos se vieron "interpelados por [un] clima de reevaluación y transformación de la idea de lo político, y se propusieron articular sus prácticas con la revitalizada praxis social, imaginando formas de intervenir en los nuevos movimientos". (LONGONI, 2009, p. 21)

El espacio público callejero se constituye para estos grupos como un ágora, como un medio propicio para la discusión, en sentido amplio, entre sujetos políticos. Como señala Leonor Arfuch, la calle deviene un "escenario obligado de participación y experimentación", pues ésta es el "territorio por excelencia de la compleja aleación entre arte, compromiso y política". (ARFUCH, 2004, p. 114)

Encuentro de dos generaciones de arte activista, cada una de ellas está signada por problemáticas distintas. Hacia el cambio de siglo en Argentina y frente a un contexto político, social, económico e institucional complejo, surge la primera de estas que irrumpe en la escena pública por medio de acciones políticas y estéticas contra un Estado cada vez más ausente $y$, al mismo tiempo, más represor y violento. Estos grupos se encuentran atravesados por una doble coyuntura que no puede pensarse separadamente. La primera está vinculada al origen de la agrupación $\operatorname{Hijos}^{2}$ y a la práctica de los escraches. Se trata de colectivos, entre los que se encuentra el GAC (Grupo de Arte Callejero) y Etcétera, que promueven acciones callejeras e intervenciones en el espacio público aportando "recursos que proporcionaron una identidad (visual y performática)" (LONGONI, 2009, p. 19) a las organizaciones de Derechos Humanos. La segunda coyuntura abarca desde diciembre de 2001 hasta mediados del 2003, momento en el que asume el presidente Néstor Kirchner.

Poiésis, Niterói, v. 19, n. 32, jul./dez. 2018. 
En dicho contexto, los grupos de arte activista toman consignas relativas al desempleo, la represión, el neoliberalismo, entre otros.

¿Qué pasa a partir del 2003 con estos grupos recientemente emergidos? Longoni (2009, p. 23-24) plantea dos cuestiones para entender el devenir de estos colectivos. Por un lado, la implementación de políticas de derechos humanos por parte del Estado produjo fragmentaciones al interior de los movimientos sociales y artísticos convocados por esa temática. Por el otro, dada la trascendencia de la insurrección argentina y la particularidad y lo novedoso del arte activista allí surgido, curadores e intelectuales europeos comenzaron a darle visibilidad en el circuito artístico y académico internacional a estas prácticas artísticas y militantes alterando tanto sus condiciones de circulación, como las redes de relaciones políticas y afectivas que tejen. Esto generó tensiones al interior de los grupos y reconfiguraciones de estos. Andrea Giunta (2009), por su parte, señala que el 2004 es el momento de la "vuelta al atelier", es decir, una suerte de repliegue hacia el trabajo individual y de la reinstitucionalización del arte que tuvo lugar a partir de la inauguración de distintos museos en el país y el auge del turismo.

Sin embargo, por varios motivos, el 2003 no puede pensarse como el inicio del fin del arte activista. Éste no escapa de aquello que Maristella Svampa (2016, p. 201) plantea en términos más generales en torno a la crisis del 2001: lo que viene luego de ésta está articulado por tensiones, rupturas y ambigüedades. Si bien es cierto que mermaron las demandas en torno a aquello que movió a la primera generación de arte activista argentino (la memoria, la verdad y la justicia relativa a la última dictadura militar y la crisis económica, política y social), el Estado se ha adapta pasivamente a las demandas del mercado mundial y ha basado su desarrollo en la promoción del consumo sostenido por una matriz productiva de tipo extractivista o, mejor dicho, neoextrativista que ha comprometido la vida y los territorios. Al mismo tiempo, las luchas contra el patriarcado también se han profundizado dada la ausencia de políticas estatales que aborden estas cuestiones y a la madurez que han adquirido los movimientos feministas. Estos ejes han configurado nuevas prácticas de arte activista y nuevos grupos, entre ellos, abordando principalmente cuestiones ambientales, se encuentra Iconoclasistas.

Poiésis, Niterói, v. 19, n. 32, jul./dez. 2018. 


\section{Mapear el Antropoceno}

Radiografía del corazón del modelo sojero. Otra pampa es posible (Fig. 1) es una cartografía realizada por Iconoclasistas entre los años 2008 y 2010 en espacios en los que participaron un amplio conjunto de movimientos sociales, asambleas socio-ambientales y organizaciones campesinas. También lo hicieron miembros de pueblos originarios, vecinos y ciudadanos en defensa de los bienes comunes, entre otros, aportando datos, relatando hechos, señalizando situaciones y también visibilizando las diversas formas de organización y resistencia ${ }^{3}$. Esta cartografía intenta poner en evidencia, en toda su complejidad, el modelo de los agronegocios y las consecuencias del monocultivo transgénico. La imagen está compuesta por un mapa físico de la región pampeana, una serie de íconos rojos, otra de íconos negros, un conjunto de carteles con textos, un pequeño mapa del monocultivo en el Mercosur en el que se recuadra el sector representado en la cartografía más grande, las referencias, el título del mapa y un texto en el que se explica sucintamente la problemática del extractivismo y los movimientos sociales de resistencia que surgen como respuesta.

Se señalan, con puntos de un color verde más claro que el de la superficie del mapa, los cultivos de soja dejando al descubierto la sobreexplotación de los bienes naturales en la región y la implantación de estos megaproyectos de manera vertical en los territorios sin consulta previa a las poblaciones. Unos pequeños íconos muestran también los puertos por los que esa materia prima es exportada a gran escala debido a una aceptación pasiva del Estado de una nueva división del trabajo internacional. Dicha exportación, según se consigna en un texto en el mapa, es asimismo un envío virtual de agua ya que la producción de granos requiere de grandes cantidades.

A su vez, los problemas sociales que son parte del extractivismo son ubicados en el territorio por medio de distintos íconos: uno que remite al desalojo de los campesinos por parapoliciales, otro a la expulsión de pequeños productores, otro a la explotación infantil y otro a la trata de personas. Los íconos rojos, en cambio, remiten a la resistencia: movimientos campesinos, Encuentros de la Unión de Asambleas Ciudadanas, la presencia del

Poiésis, Niterói, v. 19, n. 32, jul./dez. 2018. 


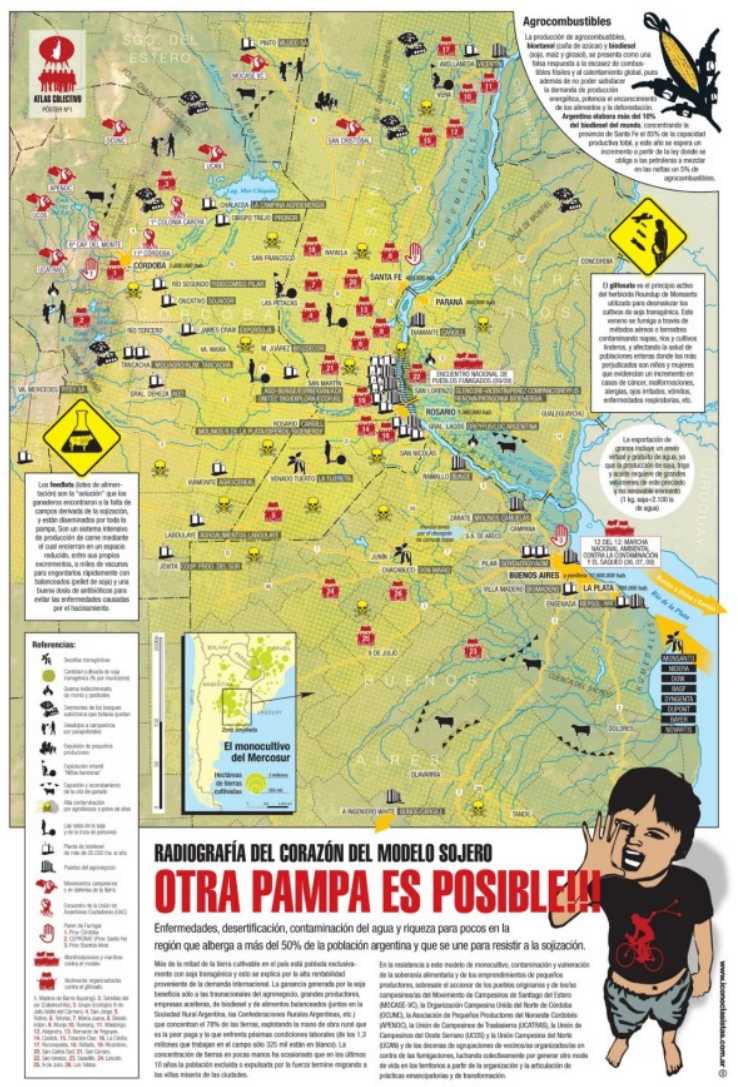

Fig. 1 - Iconoclasistas, Radiografía del corazón del modelo sojero. Otra Pampa es posible!!!, 2008-2010. medidas y soportes variables 
colectivo Paren de Fumigar, las movilizaciones y manifestaciones realizadas y agrupaciones de vecinos organizados contra el glifosato. Sobre el margen derecho se consignan también el nombre de las empresas extranjeras que comercializan semillas transgénicas y agroquímicos como Monsanto, Nidera, entre otras.

Podría seguirse enumerando, pues las referencias abundan. Sin embargo, resulta interesante subrayar la forma en la que en una misma imagen pueden conectarse las distintas aristas del problema y principalmente los diferentes modos de resistencia que en su mayoría son luchas locales que tienen lugar sobre todo en pequeñas y medianas localidades, muchas veces en territorios más aislados.

Esta imagen puede pensarse también en relación con otra que el dúo produjo en el año 2007, Develando las tramas ocultas del consumo en tres postales (Fig. 2). El extractivismo no puede ser explicado si no se piensa el modelo de consumo. Esta segunda cartografía es un mapa conceptual en el que por medio de flechas, textos e imágenes en blanco y negro se denuncia la vorágine de producción y consumo a la que, según se dice, somos sometidos. Allí se asocian ideas tales como consumo, precarización laboral, trabajo esclavo, medios de comunicación, centros comerciales, fuerzas represivas del Estado y privadas, brecha alimentaria, entre otras. La cartografía, una de las primeras que el grupo realizó, fue elaborada en base a datos de distintas consultoras, organizaciones de derechos humanos y ambientales y medios periodísticos.

En esta serie de imágenes también podría incluirse la cartografía La República de los cirujas (2013, Fig. 3). La misma es el producto de un trabajo colectivo realizado junto a trabajadores cirujas que desenvuelven sus tareas en el Complejo Ambiental Norte III, del Ceamse, en el partido bonaerense de General San Martín, en el que se arrojan diariamente 800 toneladas de residuos. El mapa pone en evidencia la geografía, la historia, los modos de trabajo, la recuperación de materiales desechados, los barrios aledaños al basural en el que viven aproximadamente cien mil personas. Basura, contaminación de la tierra y el agua, presencia y persecución policial, migración, formas de organización y resistencia, recuperación, quema, salud son las cuestiones que quedan descriptas y entrelazadas en la cartografía.

Poiésis, Niterói, v. 19, n. 32, jul./dez. 2018. 


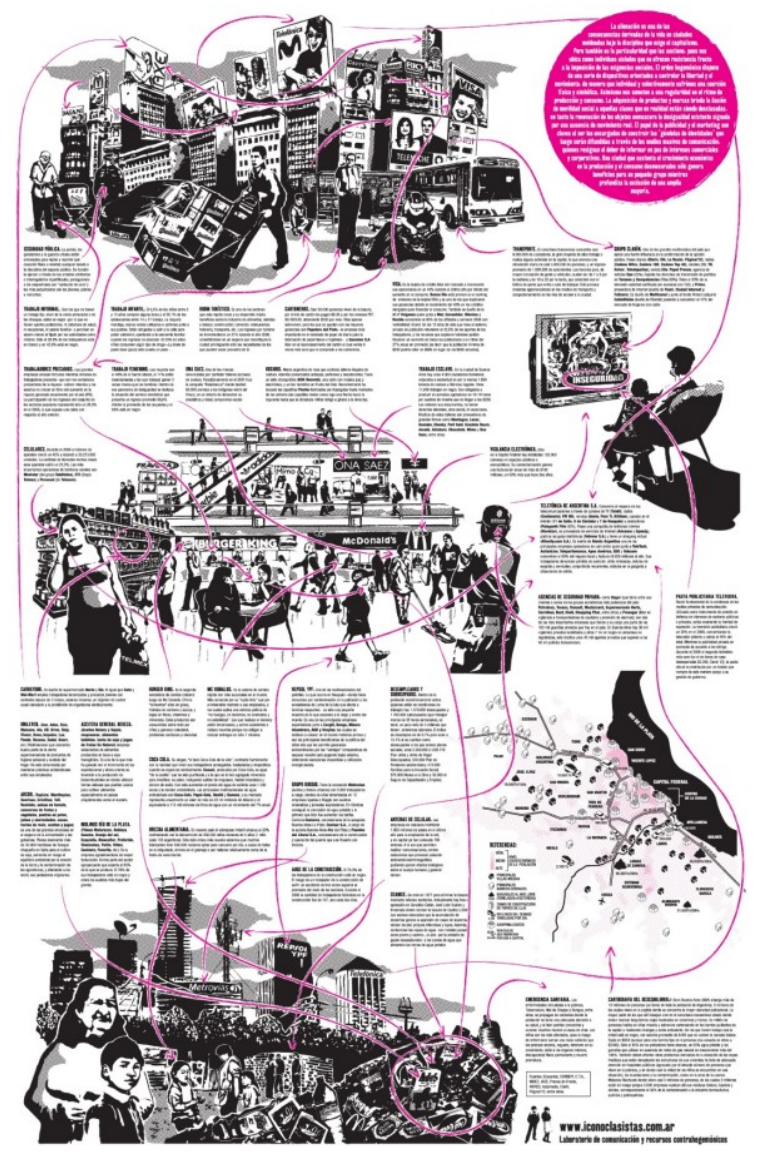

Fig. 2 - Iconoclasistas, Develando las tramas ocultas del consumo en tres postales, 2007. medidas y soportes variables 


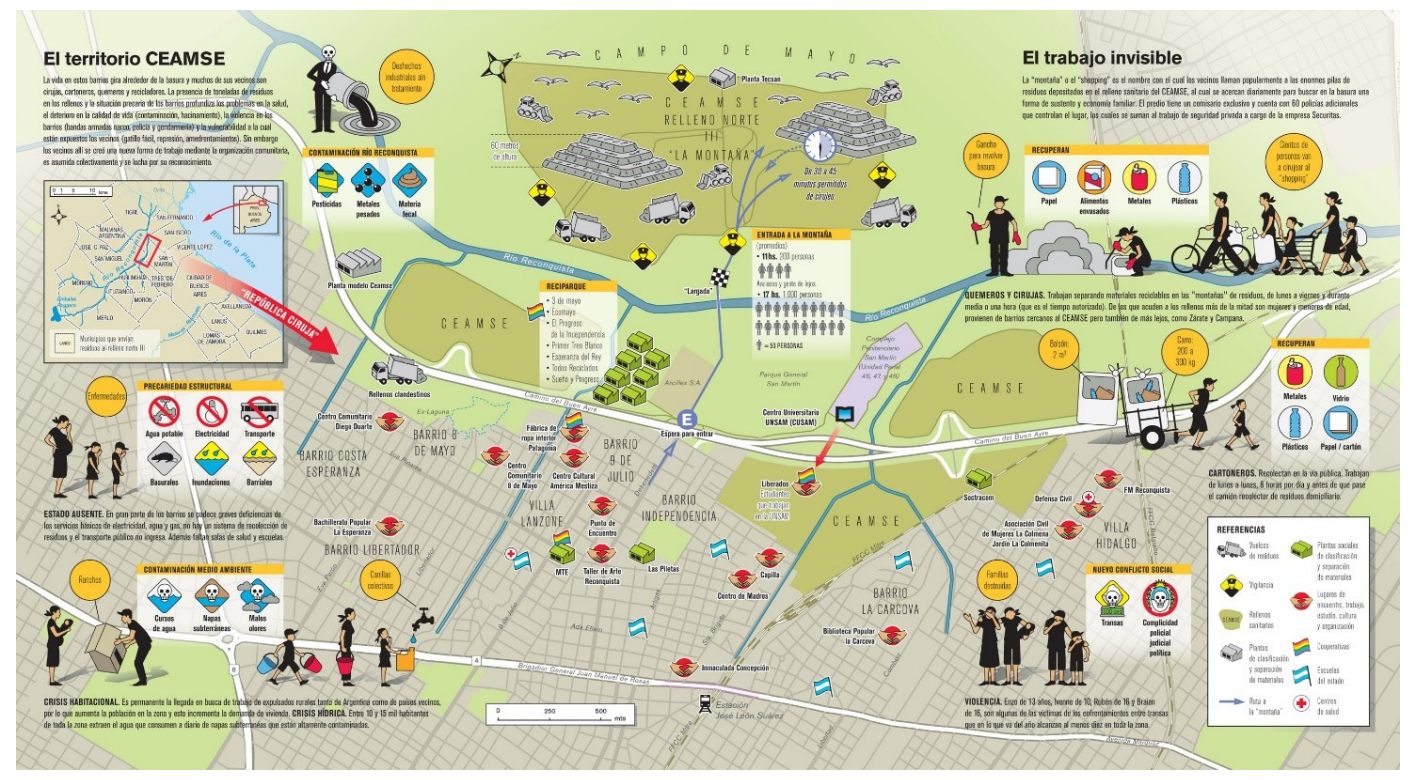

Fig. 3 - Iconoclasistas, La República de los cirujas, 2013. medidas y soportes variables 
Quisiera agregar a la serie una última imagen que mapea la resistencia por parte de los movimientos sociales. Se trata de América Latina Rebelde (Fig. 4), un mapa realizado durante el "Taller de diálogo entre movimientos sociales" en la ciudad de Lima durante dos eventos organizados por el Programa Democracia y Transformación Social (PDTG) en mayo 2010. Ante las fuerzas que intentan controlar el territorio y los bienes comunes, ante la extracción a gran escala de minerales, petróleo y gas, ante el monocultivo, ante la contaminación a gran escala, ante la represión y la criminalización de la protesta, ante la discriminación racial, de género y homofóbica, han surgido, dice la misma cartografía, nuevos y renovados movimientos sociales. Hacer un mapa con todos ellos, ubicarlos en sus lugares de acción y señalar sus estrategias, es una forma de unir los átomos que componen una misma resistencia.

La serie de imágenes y de acciones cartográficas aquí presentada tiene cuatro ejes: el monocultivo, el consumo, los residuos y los movimientos sociales. Todas ellas son, entre otras, aristas fundamentales de lo que se conoce como Antropoceno, un concepto complejo que abre un amplio campo de discusiones. Según lo determina el informe redactado en el congreso de la Unión Internacional para la Investigación sobre el Cuaternario (INQUA) en el año 2011, el Holoceno ha terminado y el Antropoceno podría ser la nueva época geológica. Ésta última se ha iniciado alrededor del año 1800, cuando comenzaba la Revolución Industrial. (CRUTZEN; STOERMER, [s.d.]) Mientras que el Holoceno se caracteriza por ser un largo período de estabilidad, en el Antropoceno la naturaleza deja de ser lineal y sus dinámicas se tornan irreversibles. La humanidad deviene una fuerza geológica de alcance global. Si bien hay lecturas más tecnocráticas de esta nueva era geológica, el abordaje de Iconoclasistas se asemeja al del ecomarxismo sostenida por, entre otros, Jason Moore. (MOORE, 2014) Para este último, el Antropoceno está asociado al capitalismo, más exactamente, al proceso de expansión de las fronteras de mercancías. Se trata de la estrategia de "producción de excedentes ecológicos" basada en la apropiación de materias primas, alimentos, fuentes de energía, y también de trabajo "barato" (o esclavo). A su vez, este modo de producción trae consigo la expulsión de poblaciones, la violación de los derechos humanos y la destrucción de ecosistemas. En términos geopolíticos, el Antropoceno se basa en una división internacional del trabajo en la que el Sur, polo de extracción, se encuentra subordinado. 


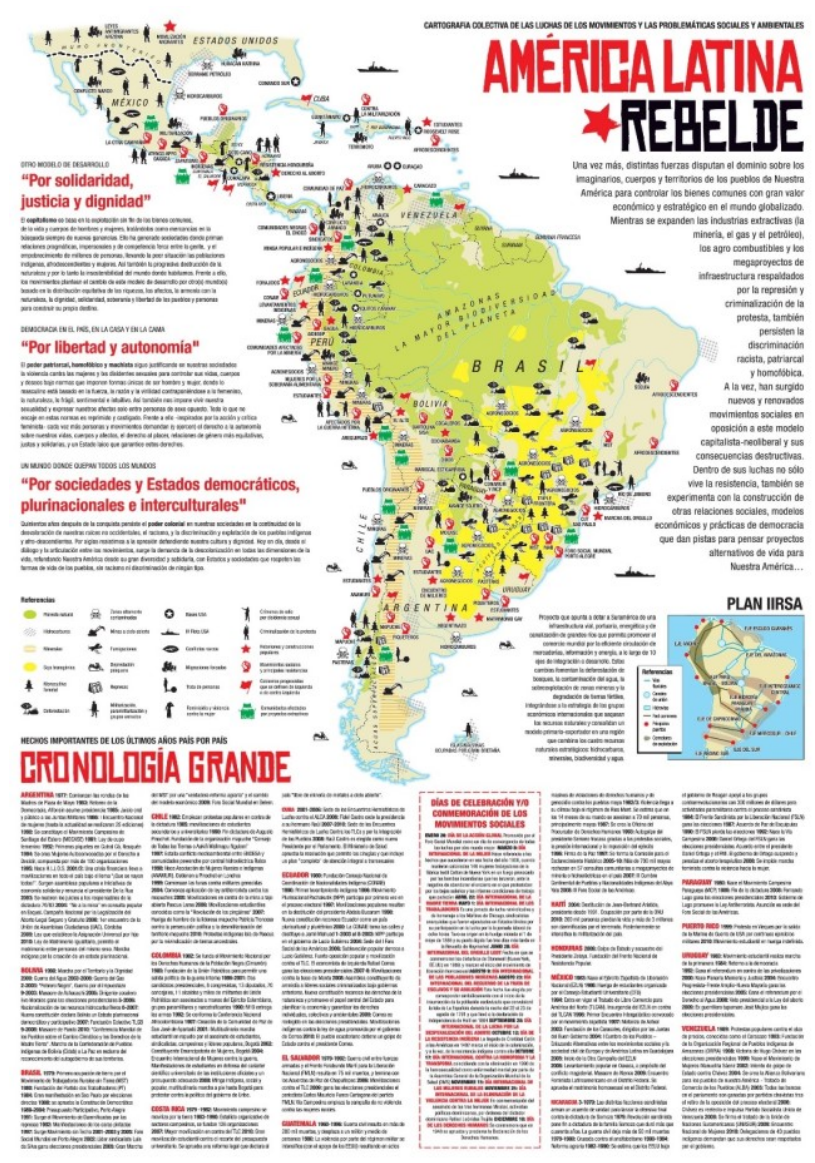

Fig. 4 - Iconoclasistas, América Latina Rebelde, 2010. medidas y soportes variables 
A partir del año 2000, Latinoamérica ha basado su desarrollo en un modelo insustentable, lo que ha generado diversos conflictos socioambientales. Por ello, los movimientos de resistencia han dado un giro ecoterritorial y han construido una nueva gramática política que busca nuevas salidas del modelo extractivo y de consumo. La serie de cartografías de Iconoclasistas presentada piensa el Antropoceno de una manera holística e integral que abarca los diferentes procesos: modelo de producción, consumo y distribución en el capitalismo contemporáneo en el Sur. Los talleres de mapeo permiten conectar los problemas y las luchas ecoterritoriales que suelen estar aisladas por encontrarse en zonas marginadas ya sean urbanas o rurales. Construir una trama de vínculos es, sin duda, una manera de fortalecer la resistencia.

\section{El mapeo como complot}

Todo mapa es un recorte o una partición de lo sensible que devela interpelaciones sobre un espacio. No es el resultado de un nexo causal capaz de legitimar lo que muestra, sino una construcción que reúne hechos y los presenta como un todo. Podríamos pensar estas imágenes a partir del concepto de Rancière de partición de lo sensible, entendido como el sistema de evidencias sensibles que muestra la existencia de un común y las divisiones que lo atraviesan. (RANCIÈRE, 2002, p. 15) Las cartografías del dúo Iconoclasistas poseen, además, una disposición de las acciones posibles que expresan un deseo realizándose: el de reconfigurar la partición de lo sensible a partir de postulados no ontológicos de igualdad y justicia.

Reflexionando sobre Aquí viven genocidas, una cartografía elaborada por el GAC (uno de los grupos que pertenece a la primera generación de arte activista a la que nos referimos en el inicio de este artículo) en el año 2001 y reelaborada en los años 2002, 2003, 2004 y 2006 donde aparecen señaladas las direcciones de los genocidas que han sido escrachados $^{4}$, sus autoras dicen: 
No hay mapas con puntos de partida fijos y lineales, sino que son recortes de una realidad sin una dirección preestablecida, guiados por una idea que los recorre a todos, que es la capacidad de movilizar, de cuestionar, de relacionar, de reconfigurar nuestras propias existencias. (GAC, p. 43)

En las cartografías de los Iconoclasistas los datos se enuncian bajo la forma de íconos, gráficos y textos. Lo desclasificado o lo invisibilizado se conecta con lo que aún está por venir, con lo que necesita una búsqueda inagotable de justicia. En Recodificaciones: hacia una noción de lo político en el arte contemporáneo, Hal Foster señala que es esta conexión la que puede "resistir a la cultura mayor, a sus apropiaciones semióticas, sus categorías normativas, y su historia oficial". (FOSTER, 2001, p. 124) Intentando construir una respuesta ante aquel gran interrogante acerca de qué estrategia debe seguir el arte y la crítica, Foster recurre a la conjunción de dos conceptos, lo menor - de Gilles Deleuze y Félix Guattari - y revolución cultural - de Fredric Jameson -. La primera de estas nociones refiere a "un uso intensivo y a menudo vernáculo de un lenguaje o una forma que distorsiona sus funciones oficiales o institucionales". (FOSTER, 2001, p. 122) Por otro lado, el concepto de revolución cultural es entendido "como un modo de restaurar la complejidad conflictual de los modos de producción y los sistemas sígnicos, que se puede entresacar de la historia misma de la cultura mayor" (FOSTER, 2001, p. 123) y que también interroga sobre - cómo nuestro propio modo de dominación explota todos los modos de producción y sistemas sígnicos, viejos y nuevos, para sus propios propósitos. Desde el vértice mismo de la conjunción de estas dos nociones, el arte debe emprender una labor genealógica - dicho en términos nietzscheanos -, o debe abogar por la insurrección de los saberes subyugados - utilizando la expresión de Foucault -, para generar una interferencia o una resistencia. Quizá esta vía que propone Foster puede ayudarnos a reflexionar sobre el uso de cierto lenguaje publicitario y del diseño gráfico en los mapas del colectivo Iconoclasistas. Dicha apropiación puede pensarse, acudiendo a la expresión situacionista, en términos de tergiversación (détournement). Pues, en estas imágenes parece haber una utilización de manifestaciones culturales conocidas para transmitir nuevos mensajes que son ajenos a los soportes originales. En este sentido, Fleisner plantea que "la propuesta de Iconoclasistas consiste en restituir al uso común (y crítico), por un lado, los co-

Poiésis, Niterói, v. 19, n. 32, jul./dez. 2018. 
nocimientos técnicos del diseño publicitario y de las estrategias comunicativas disponibles $y$, por el otro, el acervo de experiencia pasada acumulada en los diversos proyectos emprendidos a lo largo de los años". (FLEISNER, 2015)

Las cartografías de Iconoclasistas no son meros soportes comunicacionales que divulgan datos. Informar, dice Deleuze, es hacer circular una consigna y, por tanto, "la información es exactamente el sistema de control". (DELEUZE, 2007, p. 287) Las sociedades de control, a diferencia de las sociedades disciplinares definidas por Foucault, no requieren de espacios de encierro, sino más bien de información, de un sistema de consignas controladas. Las cartografías acá analizadas son vehículos de contra-información, o dicho de otro modo, de (contra-)información devenida acto de resistencia.

El mapeo, entendido como una práctica crítica y colectiva, acompaña, difunde las luchas y teje lazos entre movimientos sociales, activistas y militantes y crea formas de sociabilidad alternativas. De este modo, podrían pensarse los talleres colectivos propuestos por Iconoclasistas como parte de una práctica de justicia política, no entendida como un equilibrio entre los intereses de un grupo de átomos, sino como una polémica sobre lo común. La cuestión no es cuantitativa como lo es para el derecho o para la administración de justicia, que tiende únicamente a la celebración del juicio más allá de la justicia, sino más bien cualitativa. Lo que importa es el vínculo que se establece, la igualdad de cualquiera con cualquiera efectiviza la política al disputar la configuración del territorio.

Las cartografías habituales son más que representaciones, son interpretaciones, construcciones ideológicas, intentos de consenso que buscan borrar los litigios sobre los territorios. El mapeo como práctica crítica y colectiva implica un enfrentamiento sobre las maneras de ver y de organizar lo sensible, he allí su carácter inexorablemente político. No se trata de prácticas artísticas que formen parte de un orden superior, distinto y separado del mundo cotidiano. No representan un "mundo real" que está por fuera de ellas, pues no hay ni algo así como un "mundo real", ni un afuera del arte. Lo supuestamente real, aquello que asociado al sistema de dominación borra su carácter de supuesto, es lo que viene a fracturar y a socavar (con más o con menos éxito) estas acciones artísticas. En la 
acción, lo artístico y lo político se transforman en cuestiones indiscernibles. Cada mapeo es una forma específica de militancia que se distancia de las herramientas clásicas de la política y del lenguaje corporativo que en momentos se apropia del arte.

La relación entre estos mapas y los territorios no puede pensarse en términos de representación-representado. La elaboración colectiva de estas imágenes es en sí misma una construcción de territorios posibles, de paisajes sensibles por venir. En Por una refundación de las máquinas sociales, Guattari señala que "las cartografías ecosóficas que habría que instituir tendrán de particular el hecho de que no asumirán únicamente dimensiones del presente, sino también las del futuro. [...] arbitran el presente en nombre del porvenir". (GUATTARI, 2015, p. 389)

Si el mapeo diseña un nuevo territorio posible que surge como el producto de la colectivización de las capacidades, estas prácticas que entonces exceden la difusión de información y comunicación de una problemática social y ambiental son modos de complot. Piglia define el complot como "un punto de articulación entre prácticas de construcción de realidad alternativas y una manera de descifrar cierto funcionamiento de la política". (PIGLIA, 2007) En este sentido, un complot implica también formas de sociabilización experimentales "que se infiltra[n] en las instituciones existentes y tiende[n] a destruirlas y a crear redes y formas alternativas". Más allá de su efectividad, en los talleres colectivos de mapeo tiene lugar una colectivización de las capacidades invertidas en escenas de disenso. No importa el producto, sino el proceso, es decir, no importa la cartografía terminada sino la acción colectiva de mapear porque, como señala Piglia, "la práctica de la vanguardia consiste en construir la mirada artística y no la obra artística". (PIGLIA, 2007) La tarea no reside en representar el Antropoceno, ni siquiera en criticarlo para crear conciencia de él e iluminar a los no iluminados, sino en "la postulación de una red y de una intriga y la construcción de otra realidad. [...] En definitiva, la mera crítica es sustituida por el complot". (PIGLIA, 2007) La política del complot es una política sostenida sobre la cercanía de una derrota y en la edificación de redes de fuga y de repliegues.

Poiésis, Niterói, v. 19, n. 32, jul./dez. 2018. 


\section{A modo de cierre}

Mapear crítica y conjuntamente es armar un complot, pues, en la capacidad de creación colectiva habitan propuestas de mundos regidos según leyes distintas a las reales, lo cual, a su vez, presupone una penetración previa en el ordenamiento profundo de la realidad circundante. Iconoclasistas pertenece a una segunda generación de arte activista argentino que construye estrategias de resistencia ecopolíticas contra un modelo de desarrollo insustentable. A partir de una profanación del lenguaje de la topografía, del arte, del diseño y de la publicidad, este colectivo elabora nuevas gramáticas políticas que no sólo hacen visibles de manera holística ejes fundamentales del Antropoceno, sino que tejen vínculos y modos de hacer que complotan (o intentan) contra el modelo extractivo y de consumo. Este complot es ni más ni menos que un punto de resistencia contra el poder oficial y todo lo que éste supone, sobre todo, un cierto régimen económico. En suma, los mapeos son actos de resistencia, modos de crear y transformar las formas de existencia individuales y colectivas, modos de figurar organizaciones afectivas fluidas. La suspensión del consenso sobre lo que puede ser visto en los espacios mapeados y el litigio sobre los territorios sólo puede darse bajo formas nuevas y no fundantes de sociabilidad, bajo prácticas afectivas alternativas que cuestionen cualquier jerarquización. 


\section{Referencias}

ARFUCH, L. Arte memoria, experiencia: políticas de lo real. Pensamiento de los confines, n. 15, dez. 2004.

BATTISTINI, O.; ABAL MEDINA, P.; GORBÁN, D. Asambleas: cuando el barrio resignifica la política. In BATTISTINI, O. R. (Ed.). La atmósfera incandescente: escritos políticos sobre la Argentina movilizada. Ciudad de Buenos Aires: Asociación Trabajo y Sociedad, 2002.

CRUTZEN, P.; STOERMER, E. The Antropocene. Global Change: International GeosphereBiosphere Programme Newsletter, v. 41, p. 17-18, [s.d.].

DELEUZE, G. ¿Qué es el acto de creación? In LAPOUJADE, D. (Ed.). Dos regímenes de locos: textos y entrevistas (1975-1995). Trad. Jose Luis Pardo. Valencia: Pre-Textos, 2007.

KOBYLECKA-PIWONSKA, E. Cuestionar el consenso: Ricardo Piglia reescribe el canon argentino. Castilla. Estudios de Literatura, v. 0, n. 4, 7 fev. 2013.

FLEISNER, P. Política de los restos. Modos de hacer comunidad en las prácticas artísticas colectivas argentinas. El banquete de los dioses, v. 3, n. 4, p. 49-69, 2015.

FOSTER, H. Recodificaciones: hacia una noción de lo político en el arte contemporáneo. In Modos de hacer: arte crítico, esfera pública y acción directa. 1. ed Salamanca: Ediciones Universidad de Salamanca, 2001.

GIUNTA, A. Poscrisis: arte argentino después de 2001. 1. ed. Ciudad de Buenos Aires: Siglo Veintiuno Editores, 2009.

GUATTARI, F. Por una refundación de las máquinas sociales. In NADAUD, S. (Ed.). ¿Qué es la ecosofía? Trad. Pablo Ariel Ires. Buenos Aires: Cactus, 2015. p. 375-389.

ICONOCLASISTAS. Manual de mapeo colectivo: recursos cartográficos críticos para procesos territoriales de creación colaborativa. [s.l: s.n.].

LONGONI, A. Arte y activismo. Errata, n. 0, dez. 2009.

Poiésis, Niterói, v. 19, n. 32, jul./dez. 2018. 
MOORE, J. W. The Value of Everything? Work, Capital, and Historical Nature in the Capitalist World-Ecology. Review (Fernand Braudel Center), v. 37, n. 3-4, p. 245-292, 2014.

PIGLIA, R. Teoría del complot. Ciudad de Buenos Aires: Mate, 2007.

RANCIÈRE, J. La División de lo sensible: estética y política. Salamanca: Consorcio Salamanca 2002, 2002.

SCHWARZBÖCK, S. Los espantos: estética y postdictadura. 1. ed. Ciudad de Buenos Aires: Cuarenta Ríos, 2016.

SVAMPA, M. Revisitando la Argentina, 2001-2013 Del "que se vayan todos a la exacerbación de lo nacional-popular". In LEVEY, C.; OZAROW, D.; WYLDE, C. (Ed.). De la crisis de 2001 al kirchnerismo: cambios y continuidades. Ciudad de Buenos Aires: Prometeo Libros, 2016. p. 199-222.

\section{Notas}

\footnotetext{
${ }^{1}$ El término posdictadura no puede entenderse de un modo ingenuo. Schwarzböck señala que "la postdictadura es lo que queda de la dictadura, de 1984 hasta hoy, después de su victoria disfrazada de derrota". (SCHWARZBÖCK, 2016, p. 23) Lo que la dictadura depara con su triunfo económico sólo se hace explícito a partir de la década del '90. La postdictadura no es la antítesis de la dictadura. Si bien en esta última no hay comicios y predomina el establecimiento del miedo - que, vale decir, no empezó en 1976 ni concluyó en 1983 - y en la primera rige una democracia circunscripta a sus variantes más instrumentales, pueden señalarse ciertas notas comunes entre ambos períodos. Las políticas económicas de transferencia concentradora desde las bases a la cúspide, el proceso de fragmentación social, la disolución del vínculo colectivo, la privatización del conflicto social y la desarticulación de la capacidad de resistencia de los sectores populares, son - siguiendo a Battistini, Abal Medina y Gorbán (2002, p. 123) - estrategias compartidas por ambos regímenes.
} 
${ }^{2}$ La agrupación Hijos (Hijos e Hijas por la Identidad y la Justicia contra el Olvido y el Silencio), que comienza a organizarse a fines de 1994, reúne justamente a hijas e hijos de detenidos-desaparecidos durante la última dictadura militar, todas ellas y todos ellos ingresaban a la vida adulta (y a la intervención política) en momentos de consolidación de la impunidad obtenida gracias a las mal llamadas Leyes del Perdón (Ley de Obediencia Debida y Ley de Punto Final) y el otorgamiento de indultos a los militares responsables del genocidio contra opositores políticos que tuvo lugar durante la dictadura..

${ }^{3}$ El mapa es el producto de una elaboración colectiva que tuvo lugar a partir del contacto con estudiantes universitarios, grupos culturales y de comunicación. Luego fueron profundizados y ampliados en los encuentros $10^{\circ}$ y $11^{\circ}$ de la Unión de Asambleas Ciudadanas (UAC) en Jujuy y Córdoba, y en cuatro encuentros organizados por el colectivo de pedagogía popular Pañuelos en Rebeldía en Bariloche, Tucumán, El Dorado (Misiones) y en Ciudad del Este (Paraguay).

${ }^{4}$ Aquí viven genocidas es sin duda un claro antecedente de la práctica del mapeo colectivo. De hecho, Pablo Ares ha formado parte también del GAC y ha participado en la elaboración de esta cartografía. 